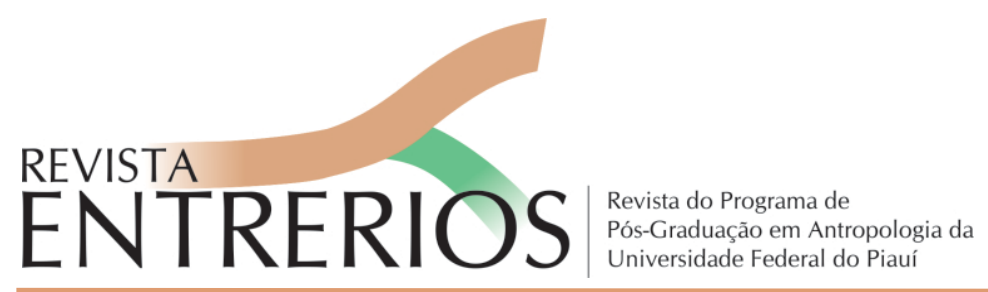

\title{
Notas acerca de los indígenas warao migrantes en Brasil
}

\section{Notas sobre os migrantes indígenas Warao no Brasil}

\author{
Ronny Velásquez \\ Profesor Titular de la UCV, Venezuela. \\ Investigador Asociado del Instituto Universitario en Democracia, Paz y Seguridad, \\ IUDPAS, UNAH. Investigador del Instituto Hondureño \\ de Ciencia, Tecnología e Innovación, IHCIETI y del \\ Instituto Hondureño de Antropología e Historia. \\ ronnyvelasquezv@gmail.com
}

\begin{abstract}
Resumen: El presente trabajo surge por la necesidad de explicar cuáles son las razones para que el indigena warao tenga la necesidad de salir de su amplio territorio, espacio que para ellos es cuasi sagrado, ya que allí viven sus dioses del origen, allí mora Kanobo, su Dios Supremo, alli están sus chamanes sus recuerdos de infancia, sus maestros de la oratoria que relatan los mitos y los cuentos del origen de su propia vida de manera diaria y que se remontan a varios miles de años. En ese espacio geográfico también tienen sus recursos naturales para vivir y sobrevivir, para desarrollarse, determinar sus aptitudes y mostrar sus capacidades y crecer como seres humanos y morir y ser "enterrados" dentro de sus tradiciones con los cantos litúrgicos de sus chamanes en su rol de psicopombos. Queremos destacar la importancia de un pueblo como el warao para sensibilizar a muchas personas que, se encuentran con ellos en procesos migratorios y que, por obvias razones, no saben quiénes son y simplemente los ven, dentro del concepto que se ha popularizado de ellos: Indios pobres del Río Orinoco de Venezuela que han salido a buscar sus propias formas de vida, porque la pobreza, la exclusión, las enfermedades, la desnutrición de sus hijos, abuelos y familia, los han obligado a migrar, en este caso, especialmente al Brasil, el Gran Coloso del Sur.
\end{abstract}

Palabras claves: Warao; Migración inducida; Cultura aborigen; Espiritualidad warao; Neocolonización; Retorno.

Resumo: Este trabalho surge da necessidade de explicar quais os motivos dos indios Warao precisarem abandonar o seu vasto território, um espaço que para eles é quase sagrado, visto que nele vivem os seus deuses originários tais como Kanobo, seu Deus Supremo, que habita este espaço; os seus xamãs, as suas memórias de infância e os seus mestres de oratória, que contam diariamente os mitos e contos da origem da sua própria vida, que remontam a milhares de anos. Esse espaço geográfico abriga também os recursos naturais para viver e sobreviver, para se desenvolver, determinar suas aptidões e mostrar suas capacidades; crescer como seres humanos, morrer e ser "enterrados" conforme suas tradições, com os cantos litúrgicos de seus xamãs. Queremos destacar a importância de um povo como os Warao para sensibilizar muitas pessoas que os encontram em processos migratórios e que, por motivos óbvios, não sabem quem eles são e simplesmente os vêem a partir de uma visão que se popularizou: Índios pobres do rio Orinoco da Venezuela, que sairam em busca de seus próprios modos de vida, porque a pobreza, a exclusão, as doenças, a desnutrição de seus filhos, avós e familiares os obrigaram a migrar, neste caso, especialmente para o Brasil, o Grande Colosso do Sul.

Palavras-chave: Warao; migração induzida, cultura, aborígene, espiritualidade Warao, neocolonização, retorno. 


\section{Políticas migratorias de corte eurocéntrico y los caminos sesgados de los warao}

Se debe confirmar desde el inicio que los pueblos indígenas en Venezuela, desde el punto de vista de la Ley, están todos protegidos, según la actual constitución modificada en 1999 y fue un proyecto político del presidente Chávez y por tanto, hubo una primera vez que en toda la historia colonial y moderna se tomaron en cuenta a todos los sobrevivientes de los sistemas coloniales y muy especialmente, aquellos que ya vivían o se trasladaron por migración forzada a lugares recónditos de un territorio, no un país, entre ellos, la selva amazónica, o a las riveras de los grandes ríos, como es el caso de los warao, que si bien, siempre a través de miles años demostrados arqueológicamente-, han vivido en el Delta del río más largo y caudaloso de Venezuela, de 2.400 kilómetros de extensión y un Delta con más de 3.000 caños de agua y una población cercana ahora a los de 49.000 habitantes, viviendo especialmente sobre las aguas del Gran Río Padre (HEINEN, 1980, 1982, 1988a, 1988b e 1992). No se puede asumir de manera tajante que viven en un "territorio" cercado. Su expansión es amplísima, de casi 44.000 kilómetros y una cuenca total de $989.000 \mathrm{~km}^{2}$, lo que la convierte en la tercera mayor cuenca de Sudamérica, atraviesa además, todo el territorio venezolano y le brinda sus beneficios también a Colombia y a Brasil. En este largo recorrido viven varios cientos de pueblos indígenas originarios y otros pueblos de criollos y hasta extranjeros que han hecho vida en el área.

A lo largo de centurias, muchos de sus pueblos completos, han tenido que emigrar en épocas pasadas, y así también, varias poblaciones indígenas o no, han desaparecido. Las razones son múltiples. De esta manera, hay indígenas warao en la actual República Cooperativa de Guyana y en Surinam, y también, hay kariña (otro pueblo indígena de Venezuela), en la Guyana Francesa (lugar que aún sigue siendo una colonia de ultramar de Francia). Asimismo, en las islas del Caribe hay actualmente descendientes de karibes y arawak originarios Suramérica.

Vemos que, los motivos son muy variados, de esta forma no se pueden resumir a la concepción que muchos analistas expresan que es la pobreza, la necesidad o la búsqueda de "otro tipo de vida" o el cumplimiento de un sueño o el fracaso de un gobierno. Desde épocas anteriores, la llegada de los religiosos, algunos de muy buena voluntad, y otros, sólo con el objetivo de reducirlos a "misiones" desde principios de 1700, los fueron reduciendo y confinándolos a pueblos para catequizarlos. El warao no ha sido rebelde, su condición de humildad hizo inclusive, que muchos de ellos fueran esclavizados. Existen muchos relatos sobre esta situación. Los warao tradicionales (ESCALANTE \& MORALEDA, 1992, GARCIA, 1971) tenían y aún poseen sus propios "maestros" que enseñaban sus tradiciones (ARMELLADA \& BENTIVENGA DE NAPOLITANO, 1991), el origen de sus vidas, su permanencia en los Caños del Delta y sus mitos genésicos (CORA, 1972). Su música, sus instrumentos musicales, sus chamanes, sus rituales a su Dios creador, Kanobo. Los warao convivieron siempre con sus animales de la selva, de sus ríos, de sus caños y también aprendieron de ellos. Así que, la cultura warao, ha sido una fuerza de resistencia para vivir, pero lamentablemente, todo su mundo de relación simbólica se ha ido desvaneciendo hasta cierto grado (no del todo) y algunos Wisi-datu (chamanes), afirman que sus dioses y espíritus los han abandonado, algunos ancianos ya no resisten a las fuerzas y presiones de la nostalgia.

Por lo tanto, entender el éxodo de los warao actuales no es muy sencillo ni se puede resolver así con conceptos que sólo pertenecen a la cultura y concepción política y materialista. Un warao que vive en el Delta del Orinoco, por sí mismo no se define pobre. Su antiquísimo río Orinoco, Padre de las aguas, ha sido todo para ellos. Allí están sus alimentos, su agua de vida, sus caminos, su destino, su nacimiento y también su muerte. Es decir, su concepción es todo en conjunto. Allí viven sus espíritus, sus jebu, sus Wisi-datu o chamanes, así como todo lo que requieren para entender su mundo cosmogónico (VELÁSQUEZ, 2008, 2016 e 2018). Esta experiencia la hemos analizado en otros contextos indígenas de América Latina o de este territorio aborigen que antes se llamó Abya Yala, cuyo concepto, de origen karibe-kuna, significa "territorio en expansión" y esta denominación es clave para entender y comprender cualquier migración de pueblos originales. De esta manera, las razones son variadas, pertenecen a un con- 
-junto de conflictos que no corresponden a su propia cultura. El warao, sigue hablando su idioma, cantando sus canciones (BERMÚDEZ, 1999), relatando sus mitos o "cuentos" (VAQUERO ROJO, 2011), los mantiene el "viejo Warao, o dueño del cuento viejo", se simboliza en el concepto denobo arotu, relata mitos y cuentos todos los días sobre el origen del mundo (LAVANDERO PEREZ, 1994; PEREIRA, 2004), el origen de los warao, y de todos los elementos (WILBERT, J., 1969, 1979, 1956a, 1995; WILBERT, W., 1995a, 1995b e 2008; MOSONYI, 2008; SUÁREZ, 1968, BARRAL, 1962, 1962 e 1980). Y aún son comunes estas historias en todo el Delta y es muy difícil (o casi imposible) actualmente encontrar a un warao que no hable su idioma y no respete su cultura tradicional.

Nosotros consideramos que una de las razones fundamentales para su migración está en nuestra propia manera de pensar desde la cultura dominante, la nuestra, se trata de comprender qué es migran sobre las "fronteras límites", que, como sabemos, es un concepto colonial. Lo que nosotros siempre hemos definido como, las cicatrices de la colonización, las cuales, hasta el día de hoy se siguen imponiendo ( $\mathrm{Y}$ aún surgen nuevos países en pleno siglo $\mathrm{XXI}$, o por razones políticas o por reconocer -con razón- alguna etnicidad determinada). Así se impone o se enfrenta a un entendimiento que sigue siendo colonial aunque aún seamos tradicionales y, a la vez, modernos. En este continente nuestra educación, nuestra antropología, la salud y la medicina, las formas de transportarnos, nuestras disciplinas todas, y hasta la cultura que se impone, siguen siendo y manteniendo sesgos coloniales. De esta manera, sin analizar circunstancias particulares de la multi y la pluriculturalidad, asumimos de una vez y para siempre el concepto "patria", según la nación en que hemos nacido. Los indígenas no. Ellos viajan de un lugar a otro de su ámbito y si son "gente de agua", como significa su nombre en warao, irán quizás, si pudieran, hasta el Delta el Río Amazonas, Branco, Negro, Río de la Plata o a diversos otros ríos de otras áreas, porque para ellos ese es su ambiente por más 10.000 años (KOCHGRÜMBERG, 1924). Y lo mismo ocurre con otros pueblos que hoy, a fuerza de sus políticas colindantes, viven en fronteras. Así ocurre con los yanomami, viajan de Brasil a Venezuela o lo contrario. También como los wayúu, son binacionales, entre Colombia y Venezuela, o los shuar, viajan y viven entre Ecuador y Perú y, asimismo, los mapuche, entre Argentina y Chile, y entre los maya-chortí, entre Guatemala y Honduras y los mískitos de Honduras, entre Honduras y Nicaragua, o los kunas de Panamá, entre Colombia y sus islas y territorios selváticos de Panamá, o los guaymí o Ggabe, entre Costa Rica y Panamá, o los emberá, entre Colombia y Panamá, o los garífunas (de origen africano, pero nacidos en El Caribe), que viven en cuatro países, como Belice, Guatemala, Honduras y Nicaragua, y los guaraní o los quechua que son, por antonomasia, dos de los pueblos más transfronterizos de Suramérica y, asimismo, entre Canadá y Estados Unidos, o entre México y esa gran nación del Norte, y así, un montón de etcéteras (GILIJ, 1965).

Las razones más inmediatistas las vamos a explicar ahora, dentro de universos impuestos de manera oficial y propuestas económicas, bajo la fuerza de la neocolonización:

1.- El Caño Manamo.- Según diversos estudios y análisis se estima que el problema del Caño Manamo se debió a la inexistencia de un estudio serio de impacto ambiental ya que sólo pretendía llevar a cabo un proyecto agrícola y pecuario en el Delta del Orinoco para solventar las deficiencias agroalimentarias en la población creciente del complejo minero e industrial de Ciudad Guayana, San Félix y otras poblaciones que crecían aceleradamente en el desenvolvimiento de ese entendido “desarrollo" que se planteó en la época del presidente Raúl Leoni, entre 1964 y 1969 y que duró varios años aun con Rafael Caldera, los 5 años subsiguientes, cuyo gobierno no solamente siguió adelante con este avasallamiento de la región deltana, sino también fue un defensor a ultranza del terrible proyecto que él mismo llamó "La Conquista del Sur", que consistía en "desarrollar"el área del Amazonas de Venezuela sin inferir las consecuencias que este ecocidio podría causar más adelante. 
Es así como se planifica el cierre del Caño Manamo, proyecto auspiciado con dinero de capital privado de Estados Unidos con el fin de encauzar más el agua del Gran Río Orinoco para facilitar la entrada y salida de barcos internacionales por la llamada Boca Grande de Navíos, durante todo el año (períodos de sequía también) con el fin de extraer por esta vía, el petróleo venezolano y el hierro de la región. Estas son fundamentalmente las causas que provocaron uno de los mayores fracasos de planificación "desarrollista" aplicada por la Corporación Venezolana de Guayana /CVG) que había sido fundada en diciembre de 1960 como dependencia de la Presidencia de la República bajo el mandato de Rómulo Betancourt. ¿Qué se planteaba? Supuestamente "el desarrollo de la región de Guayana". ¿De qué se ocupaba? De los recursos forestales, hierro, bauxita, oro, diamantes y otros minerales, supuestamente para el desarrollo económico e industrial del país y el desarrollo hidroeléctrico. Y del pueblo indígena warao no se dijo absolutamente nada. Las consecuencias negativas se vieron palpables a lo largo de 50 o 60 años más las cuales aún se padecen. Las propuestas desarrollistas de ellos fueron para el gran público venezolano, pero no para los indígenas, sus antiguos moradores. Estuvieron referidas a "sanear" de inundaciones un total de 900.000 hectáreas de terreno anegado por aguas del gran Río Orinoco, de las cuales, sólo apenas 140.000, según sus argumentos eran aptas para la agricultura y la ganadería de forma natural.

El proyecto se inició con la construcción de un gran sistema de diques y no sólo se haría el de Caño Manamo, sino que se seguiría hacia otros brazos del río Orinoco. El hecho nefasto se realizó, y especialmente en las zonas más pobladas del delta del Orinoco, entre ellas, los espacios entre Tucupita, la capital del estado, la isla Macareo, Manamito, Cocuina, Guara y territorios que pertenecen al estado Monagas donde hoy se observa pobreza extrema entre sus habitantes, a quienes ya nada les ha quedado para sobrevivir de forma natural, ni peces, ni cangrejos, ni palmas de moriche, y hasta los chamanes warao de la zonas se han muerto del propio desespero ya que no han podido hacer nada en contra de las nefastas consecuencias de ese mal llamado "desarrollo". Es necesario tomar en cuenta que en esta área vivía el 80 \% de la población deltana, por esta razón allí está asentada su capital, Tucupita, el pueblo más cosmopolita de la región y con grandes cinturones de miseria para los indígenas warao que han salido de sus caños para hacinarse en el área y, en este caso, es una responsabilidad decirlo, es un compromiso profesional reconocer que por lo menos ellos que pertenecieron a la cultura del agua (muchos warao de estas regiones), ahora permanecen dentro de la cultura de la basura.

El gran Río Orinoco o Río Padre y sus caños de agua abundante juegan un papel extraordinario en la calidad del sistema fluvial y en la vida de los que allí habitan. Entre sus efectos beneficiosos es necesario destacar que con las crecidas del río se aportan de forma natural los sedimentos necesarios y ricos para los suelos, este conocimiento lo poseen los indígenas warao, quienes, al igual que los egipcios con el Nilo, sabían manejar bien su ecosistema y sus crecidas son a la vez, su propio calendario. Por otro lado, las crecidas ejercían el papel de drenaje de deshechos naturales hacia el mar, ahora, con la llegada del comercio y con la imposición de hábitos de alimentación y de bebidas alcohólicas en estos pueblos, el río Orinoco, Padre de las aguas, está en peligro por la descarga en él de deshechos ferrosos, además del plástico, aguas negras, latas, metales herrumbrados, cauchos de vehículos y cualquier otro tipo de deshechos dañinos que producen las industrias menores y mayores en esa área superpoblada que fue intervenida por la fortaleza de gobiernos irresponsables que nunca pensaron en las consecuencias a futuro. Así, ahora, se comprueban los resultados porque el Río Orinoco lleva además heces humanas y materiales en descomposición y putrefactos para los warao en general -muy especialmente- que deben beber el agua del Gran Río Orinoco, Padre de las Aguas, que es el don que les dio la naturaleza.

Por otro lado, las aguas salobres del mar que siempre estuvieron en lucha con la fuerza de las aguas del Orinoco, cuando entran al mar por la vía de Pedernales, estas aguas salobres, oscuras y contaminadas penetran a su vez, las aguas del Orinoco que desbordan el cierre y en algunos sitios hasta 45 kilómetros aguas adentro, no sólo por Caño Manamo sino también por otros caños del gran delta. 
En este caso, este efecto de salinización de las aguas del gran Río Orinoco, ha causado estragos en la población infantil que utiliza las aguas con fines domésticos, y además, ha causado efectos terribles en la producción de la tierra para la alimentación de la familia. Asimismo, ya no se produce el palmito, planta tradicional que el warao utilizaba como alimento. También, ha causado cambios en la producción de animales comestibles como peces, cangrejos, caracoles, tortugas, iguanas, etc., que ya no se producen de la misma manera, ahora el warao tiene que comprar sus alimentos en los abastos y supermercados sin saber, de manera adecuada, cómo entrar o estar insertos en ese mercado del gran capital.

Ahora los suelos de los warao son superficies con abundantes ácidos sulfúricos que las vuelve inútiles para las actividades agrícolas y una planta acuática conocida como nenúfarBORA se ha vuelto una plaga en los caños del delta la cual va creando terrenos fangosos por su amontonamiento en millares de hectáreas y esta realidad ha traído también, por consecuencia, la desaparición de animales comestibles que por miles de años alimentaban a los warao. Además, esta planta, impide el libre desplazamiento por el río, en sus embarcaciones tradicionales a vela o a remo, lo cual les trae desazón y cambios profundos en el desenvolvimiento de su psicología social. Por otro lado, en los caños, donde ahora el agua es más abundante por el dique, los niveles de anegamiento son descomunales y en este caso, ha traído muerte a la naturaleza como la caída de grandes árboles que fueron íconos importantes en la vida del warao tradicional (GUANIRE, ARANGUREN \& GONZÁLEZ ÑÃNEZ, 2010), así como también desparecieron millares de palmas del moriche, de la manaca y de palmito y entre tanta destrucción, de igual modo, se han muerto de infecciones y de enfermedades extrañas muchísimas personas, y las que han podido salir a tiempo de este terrible holocausto causado por esta intervención a la naturaleza, ahora, son los que forman parte de los cinturones de miseria de Tucupita, Caracas, Ciudad Bolívar, Puerto Cruz, San Félix y otras ciudades del territorio nacional y desde hace unos cuatro o cinco años, se han desplazado hacia los territorios brasileños de La Línea, Pacaraima, Boa Vista y Manaos (GARCIA-CASTRO, 2001, 2000a, 2000b, e 1999), , y posiblemente, seguirían hasta el Delta el Gran estuario del Amazonas, si fuese posible. Estos presidentes mencionados y muchos otros después de ellos, nunca tuvieron conciencia del daño que hicieron, pero la historia no los podrá poner en el exilio de estas acciones ecocidas y genocidas.

Resumiendo, hasta los animales de sus selvas, en estas áreas se murieron y muchos pueblos o aldeas desaparecieron. Pronto llegó la gran soledad y el abandono ${ }^{1}$. Podemos afirmar que ni a los gobernadores ni a los alcaldes del Estado Delta Amacuro, -que todos han sido criollos-, no les ha interesado la vida de los indígenas warao. Sólo los visitan en sus municipios, en épocas de elecciones.

2.- Yakariyene.- Conocida la presencia de miles de indígenas warao viviendo en los alrededores de Tucupita, capital del estado Delta Amacuro, y otros lugares fuera de los caños, otro presidente desarrollista como Carlos Andrés Pérez, en la aplicación de su política de "viviendas rurales", promovió "casas" inadecuadas para esta zona, pequeñas, de bloque y zinc, y así, además de "facilitar" hasta cierto grado, mano de obra indígena y barata, se fueron fundando barrios completos en esos 50 kilómetros de territorio entre el puerto fluvial llamado Volcán, a orillas del Orinoco y a 3 kilómetros del llamado "Cierre" o puente del embalse del Caño Manamo para llegar hacia la ciudad de Tucupita, esta población de Volcán y a través de los 50 kilómetros hacia la capital, fue creciendo sin control alguno (solamente en las localidades fundadas por criollos) asimismo, creció una población "marginal" con casi ningún hábito de higiene ni de una salud adecuada. Es así como nace la idea del mismo Presidente de construir con materiales inadecuados una gran "Casa Comunal" para todos los indígenas warao que buscaban posibilidades de trabajar dentro del área de Tucupita. Esta casa que existió por muchos años fue llamada Yakariyene, la que al final, se convirtió, en un lugar invivible y en ella, sin embargo, se fueron refugiando para coexistir de manera permanente todos los warao que llegaron de diversos caños del Delta y que, sin ninguna higiene, agua adecuada, privacidad, allí se colgaron miles de hamacas (chinchorros o mosquiteros), para establecer su espacio de vida, ya que ellos no poseen

\footnotetext{
1 Necesario sería ver el documental "Caño Manamo", del cineasta Carlos Azpúrua, así como "Amazonas el Negocio de este mundo", del mismo director.
} 
concepto para definir una casa, sino que conceptúan su hogar como ja-noko, "el lugar del chinchorro".

Esa casa que poseía una concepción política, la diseñaron a las orillas del Caño Manamo que corre por toda la orilla de Tucupita. Esa misma casa, con el tiempo se volvió una especie de covacha para permanecer en ella y así se facilitaron vicios, enfermedades y extremas formas de vida inadecuadas. Al final, después de más de 25 años de uso, se destruyó casi por sí misma y así, sus moradores que habían hecho a lo largo de tantos años "su hogar", se vieron forzados a salir de allí, pero ya no regresaron a sus caños. Allí nacieron hijos, nietos, hermanos, formaron familia, otros murieron y, por todas sus dificultades, empezaron a migrar a los barrios de Tucupita, o de otras ciudades cercanas, y se convirtieron en obreros, jornaleros, mendigos. Así, no podemos esperar una población indígena arraigada a su espacio u orgullosa de su etnicidad, sino presta a convertirse en parias de un destino incierto.

3.- La extracción de sus recursos.- Fueron también, otros de los motivos para forzarlos o permitir su salida, es decir, hubo, emigración forzada. Los warao, siguen siendo dependientes del moriche (Mauritia flexuosa), una palmera de estas áreas que les da todo para vivir, por eso le llaman "árbol de la vida". Luego, se instalaron en el área compañías canadienses extractoras del palmito, que era uno de los alimentos tradicionales para el warao y este fue agotado, así como sucedió con la pesca indiscriminada o diferentes tipos de cacería llevadas a cabo por personas no indígenas, es decir, criollas o extranjeras.

4.- La poca atención a la salud.- Es otro de los factores, pues al haber crisis de combustible y cuando estos productos caen en la mafia de su venta, no hay manera de dirigirse a las comunidades ni de ellas a Tucupita. Las habilidades de trasladarse por curiara o embarcaciones a remo se han ido perdiendo desde hace años y además, dependiendo de los lugares de vida en sus intrincados caños, se demorarían semanas en un traslado hasta el puerto fluvial Volcán, que como ya dijimos está ubicado a 50 kilómetros de Tucupita, ciudad donde funciona un hospital. Cuando hemos visto emergencias, como la mordida de una serpiente venenosa, el agredido puede morirse en el camino y lo mismo pasa con una joven embarazada, si ya no existe la partera o comadrona en su comunidad. A los chamanes wisi-datu, o parteras diawara-mojo-namina, los han ido desapareciendo u ocultando por razones "sanitarias o religiosas". En síntesis, no hay manera de entender de otra forma la solución de estas urgencias tan necesarias en los pueblos con culturas indígenas que por miles de años han sabido manejarse en su ambiente y en todas sus necesidades humanas, sanitarias y mortuorias. Pero la sociedad dominante ha invadido todos sus espacios llevándoles objetos para que cambien su vida, es como se dice, "para civilizarlos" o hacerlos dependientes, porque hasta féretros les hacen comprar para sus muertos y les exigen un cementerio cuando ellos poseían sus propios sistemas de enterramiento.

Otras razones - Ahora, por falta de medios de comunicación es poca la presencia de invasores en el área del gran Delta del Orinoco y porque, además, casi nada ha quedado para explotar, por estas razones, no existe hasta hoy, en plena pandemia, ningún caso de coronavirus entre los warao de Delta, pero tenemos información que ha llegado por medio de migrantes que partieron hacia territorios del Brasil y algo peor aún, muchos garimpeiros o aventureros buscadores de oro, ya llevaron el virus a indígenas yanomami que viven en chabonos del lado del Brasil, en plena selva amazónica. Todo esto es muy complejo entenderlo de una sola vez, en el caso de las migraciones forzadas, porque esos actos de buscar otros espacios por razones de obtener alguna seguridad para seguir viviendo, es irse a la aventura de un futuro incierto que puede convertirse en holocausto y los causantes de estas migraciones, sin quererlo quizás, o por su avaricia disfrazada y desmesurada, son los que provocan este genocidio.

Por otro lado, la crisis producida por el bloqueo económico para Venezuela que incide en el desabastecimiento de productos o en la especulación de toda índole y a falta de los insumos para producir la gasolina, las medicinas e infinidad de otros necesarios ahora para la vida en cualquier parte del planeta, ha causado el agotamiento de los recursos naturales de estas áreas del Delta del Gran Río Orinoco, así como también se están acabando los recursos necesarios para simplemente vivir y hasta el agua y el oxígeno de la Amazonía, o de otras selvas de nuestro continente que están actualmente en peligro. 
El puerto fluvial Volcán, ubicado a casi 800 kilómetros de Caracas, se ha convertido en una frontera límite con todo tipo de problemas: Tráfico ilegal de productos de toda naturaleza, contagio de enfermedades endémicas, trabajo sexual y abandono de todas las normas. Los warao que ahora han conformado un pueblo en el área, a orillas del Caño Manamo u otros ramales del río Orinoco e incluso hacia adentro en los extendidos manglares y humedales del gran estuario, muchos viven sin condiciones favorables. Estamos hablando de esos 56 kilómetros aproximados entre el puente de El Cierre, sobre el Caño Manamo hasta Tucupita, y luego, más allá de dicha ciudad, hacia sus depósitos de basura y territorios aledaños, localizados en la franja gasífera y petrolera en dirección a las costas y lugares abandonados, por supuesto no aptos para vivir. En la zona existieron pueblos desahuciados, herederos de los efectos del Caño Manamo, hoy sólo quedan lugares aptos para crear cerdos y sembrar otros productos alimenticios regionales como el ocumo chino o el plátano.

\section{Orinoco en su largo recorrido va dando vida a millares de kilómetros de tierras vírgenes}

En Venezuela, también tenemos migración de pueblos del Sur del continente, los yeral de idioma ñengatú son uno de ellos, tradicionalmente vivían a lo largo del Río Negro o en las regiones de San Gabriel de Cachoeira. Hoy se asentaron y viven en las riberas del río Guainía, que nace en Colombia y que es afluente del Gran Río Negro, que también recibe aguas del Gran Río Orinoco, a través del Río Casiquiare que se desprende del Río Padre Orinoco, muy cerca del pueblo yek'wana de Tama-Tama, en su recorrido hacia el norte, en dirección hacia el Océano Atlántico. Este fenómeno extraordinario de nuestro Río Padre, es el que llamó tanto la atención del naturalista alemán, Barón Alexander Von Humboldt (1967), quien viajó hasta estas regiones a finales de 1700 y principios de 1800 para posteriormente, escribir sus famosas obras, Viaje a las Regiones Equinocciales del Nuevo Continente. Así, el Orinoco en su largo recorrido va dando vida a millares de kilómetros de tierras vírgenes, a cientos de poblaciones indígenas, creando caños, senderos, y hasta un gran río como lo es el Casiquiare, Kashishare que en lengua yek'wana significa "agua antigua".

Orinoco, "soberbio" como lo llamó el escritor francés Julio Verne, es un río que nace en las fronteras con Brasil y va a desembocar en el Océano Atlántico, cerca de la actual república de Trinidad y Tobago. En este caso, si los ríos nacen en un territorio determinado por una división política después de las independencias y atraviesan otros países, su problema no es de nacionalidades, es un problema humano. Los ríos, las montañas, los macizos, las cordilleras, los tepuyes (que significan pilares o árboles de la vida de piedra granítica), de la Gran Sabana, los mares, nacieron hace millones de años y, sin embargo, se han repartido entre "países", asimismo, los pueblos indígenas que vivían allí hace miles de años, quedaron repartidos como "objetos de la naturaleza" y muchos de ellos -miles y hasta algunos millones-, también fueron exterminados por la fuerza de la colonización y los que aún quedan, sobreviven con su gran nostalgia, habiendo perdido, algunos de ellos, sus idiomas originarios, en los cuales se refugiaban sus ancestralidades, sus religiones propias, sus dioses de la naturaleza, sus rituales y, en síntesis, todas sus culturas. Nosotros, la cultura dominante, hemos matado a sus dioses ancestrales y vaciado a sus mitos, relatos y su etnohistoria, de su contenido simbólico.

Sin embargo, los warao siguen siendo muy homogéneos y actúan siendo artesanos de la fibra del moriche: tejen sus sueños en la elaboración de hermosos chinchorros, (hamacas), cestas e infinidad de productos de esta fibra, que ahora salen a vender a Brasil para adquirir divisas debido a la gran devaluación de la moneda nacional, el bolívar, que hoy día ha llegado ya a 300.000 en base al patrón dólar, y cada día sube por la especulación de un mercado paralelo que no tiene control, ni es fácil explicar cómo es que opera. Esta situación no es desconocida, cuando ahora los warao tienen que comprar productos, no pueden vender un chinchorro por 300.000 bolívares, que es lo que vale medio kilo de carne, azúcar, sal o un potecito de aceite para freír un pescado.

Así, por lo que hemos investigado, estos warao que viajan al Brasil, no se quedan allá. Sin embargo algunos de sus familiares se han asentado en esos territorios esperando que pase el vendaval de lo que ocurre en Venezuela. Allá se queda un enlace para establecer los negocios de 
sus artesanías, pero, en este caso, muchos de los que han ido son una población flotante que por la urgencia ha emigrado. Se van en autobús desde San Félix en el estado Bolívar, permanecen allá por dos tres semanas, meses o hasta más largos periodos, pero entendemos que luego retornan a su amado río Orinoco a pesar de todas las dificultades. En este caso, sería necesario hacer una investigación profunda entre los warao asentados en Brasil, es decir, los que se han quedado allá y no tienen en mente regresar o los que siguen su ruta más al Sur, porque de los que se han ido y han vuelto tenemos suficiente información actualizada hasta el día de hoy e inclusive por medio de un enlace que vive en Manaos, hijo de una gran colaboradora nuestra que se llama Carmen Medrano, cultora, artesana, él se llama Yeser Quintín Díaz Medrano.

Ahora bien, la mayoría de los que viajan viven en estas zonas vulnerables de Volcán y áreas de Tucupita, que también hablan castellano perfectamente. Algunos han estudiado, saben leer y escribir, han participado en actividades fuera de su área, ya sea en exposiciones. Algunos también han viajado fuera del país invitados para lucir, vender o demostrar su arte del tejido o hasta para demostrar sus habilidades musicales con los instrumentos más conocidos, entre ellos, flautas de carrizo, bambú y su famoso Seke-Seke o violín warao, tal como ha ocurrido con nuestro amigo músico y compositor Mokovito. Muchos de ellos, se han dado a conocer como compositores y cultores en otros países gracias al beneficio que sólo fue posible dentro de los programas incluyentes del gobierno revolucionario. Muchos también, ya no tienen un comportamiento "gregario" desde el punto de vista social, como lo poseen los warao de los caños adentro; algunos ya han nacido en Tucupita, u otros lugares fuera de los caños. Por estas razones deseáramos investigar más de cerca esta realidad, y saber además el número más aproximado de migrantes warao en Brasil. Necesitaríamos para ello datos de los colegas brasileños y podría ser en este caso un trabajo en colaboración, dado que el tema por ser novedoso, es complejo y de por sí muy interesante. Sólo así, podría afirmarse si se quedarán allá, si tienen la convicción de formar un nuevo pueblo o regresarán a sus caños, una vez que pase la avalancha de dificultades y si es que se quedan allá, tienen derecho a migrar, pues poseen varios miles de años en estos espacios que les corresponden por derecho propio; a lo mejor, el Amazonas fue su lugar de origen como ya se ha planteado antropológicamente desde hace varios años respecto a la mayor parte de todos los originarios indígenas de Suramérica².

Necesario es también reconocer que muchos de ellos pertenecen a la religión católica, evangélica, adventista, iglesia de Dios, etc., y poseen abundantes conexiones. Otros se sienten desubicados porque admiten que sus propios mitos no encajan en estas formas ajenas de pensar. Y sus chamanes ya no cumplen el papel de ser "médicos, sacerdotes, psicopombos" naturales, o porque se han muerto, porque no son tan eficaces ante las nuevas enfermedades, porque son objeto de persecución o burla por parte de las nuevas autoridades, de los representantes de las iglesias o de una sociedad dominante que avasalla sus posibilidades para que puedan entrar en cánones que sólo responden a las necesidades de quienes requieren de sus productos naturales, como el pescado, la manta raya, tortugas, palmito, la madera, la fibra, productos agrícolas, como el ñame, ocumo, cangrejos que se reproducen por millares entre los meses de agosto y septiembre. También están otros motivos como el trabajo de obrero o asalariado, en donde ahora viven criollos y hay pulperías o casas de refugio, pensiones $u$ hoteles que necesitan de sus productos para la elaboración de comida a turistas, investigadores, profesionales, viajeros, aventureros de diversas procedencias, etc., que circulan por todos los caños del Delta del Orinoco, pero sus productos son pagados muy por debajo de un precio adecuado. Así, aunque estos bienes sean necesarios en unos territorios acuáticos que sólo los warao saben manejar por el conocimiento armónico de convivir sobre un río que recibe el agua el mar cada 6 horas y es esta la manera: o se vive entre el agua y se camina sobre andenes, o se vive en el fango y se camina entre el lodo en donde solo ellos pueden manejar su vida para adquirir sus bienes.

Estos acervos ahora son intercambiados de manera desigual o por poco dinero que sólo favorece al "comprador" o por productos de la cultura criolla, como ollas de aluminio, láminas de zinc, ropa usada, nylon para pesca, anzuelos, clavos, bienes de las ferreterías o alimentos no

2 Se recomienda leer los escritos de Betty Meggers (1976). 
tradicionales para los warao, entre ellos, espaguetis, harina de trigo, medicinas, sardinas en latas o diversos enlatados, además de otros objetos como fósforos, cobijas usadas, jabón, y un sinfín de productos que no son equitativos al trabajo indígena para producirlos. Lo mismo ocurre con sus artesanías y muy especialmente con cestas y hamacas, su trabajo es enorme, desde extraer la fibra de moriche, procesarla, hervirla por largas horas, llevarla al color requerido, pintarla con jugos de plantas tintóreas, hasta concluir con la elaboración de las mismas. Es una labor abrumadora que hacen con sabiduría. Su arte es admirado, pero no es bien pagado en el Delta del Orinoco. Otro aspecto importante que no se debe poner en el exilio, es que algunos warao ya poseen, por sus propios esfuerzos, algún motor fuera de borda, una lancha, lo cual es necesario para hacer servicios y circular por el Delta, comprar gasolina, aceite, bujías, y darle, igualmente, mantenimiento a sus motores, lo que se ha vuelto imposible desde hace varios años.

De esta manera, ahora padecen enfermedades de la cultura dominante, pues durante tanto tiempo, han aprendido a usar los bienes comerciales de la cultura que se impone y, en el caso particular de los warao, también han sido abatidos en algunos lugares, por el virus del VIH (SIDA) ¿Cómo? A través del trabajo sexual de jóvenes, mujeres y hombres, quienes han entendido que vender su cuerpo temporalmente es una forma de adquirir el dinero que requieren para poder vivir en una sociedad que se les impone. Tradicionalmente el warao posee dentro de su cultura y, es aceptable de manera natural, a un personaje llamado tira-wina, o tidawina, que significa "como si fuera mujer". Esta persona con el tiempo, se convirtió en travesti y fue fácil presa de gustos exóticos con personas foráneas, ya fuera en Tucupita, San Félix o en lugares más poblados, y en su encuentro con individuos portadores del virus, se contaminaron y también se infectaron entre ellos mismos. Muchos ya han muerto de esta enfermedad y los más mayores, los chamanes, los médicos tradicionales, entienden que esta es una enfermedad producida por un espíritu vengativo que ellos no pueden dominar. Los casos más conocidos han sido los de Guayo, Jobure de Guayo y Muraco. Algunas personas criollas muy machistas han visto este hecho como abominable, los han maltratado por ello y han emitido comentarios negativos homofóbicos y transfóbicos.

\section{Se van con la esperanza y con el fin de volver a sus caños tradicionales}

Por miles de años, el pueblo warao ha resistido a las inclemencias de diversos tipos de agresión. Por lo tanto, su resiliencia está demostrada. Conocemos que por ser un pueblo pacífico, hasta fueron objeto de cacería y apresamiento para ser vendidos como esclavos durante mucho tiempo, en épocas de conquista y colonización. Estos datos son parte de su cultura tradicional, posteriormente, ya en plena época republicana, sus territorios, especialmente, las áreas que más poseen tierra firme, fueron tomadas por pescadores de la isla de Margarita que son criollos y también las áreas más apetecidas de las riberas del Orinoco, especialmente las más altas, para siembra, cosecha o cría de ganado, fundamentalmente vacas y cochinos que no pertenecen a su cultura tradicional.

Consideramos nosotros, que ahora, con los abundantes problemas económicos, con el uso de una moneda nacional devaluada todos los días, con una inflación actual que supera el 15.000 $\%$, de acuerdo con la International Monetary Fund, en cuyos datos pueden observarse que es la más alta del mundo. Sin embargo, no se explican las razones, ni de bloqueo, ni de ninguna otra causa sobre la cual se afecta la economía nacional y con un dólar llamado Dólar Today, o "negro", que no se maneja en el país, sino en Colombia y, en general, desde el exterior.

Es evidente que los warao no van a analizar esta situación, ni tampoco los eñepa o panare, tampoco los pemón de la Gran Sabana, que viven al sur del país y colindan con la vecina gran nación de Brasil. Para ellos, esta es una realidad, es la que conocen y también se informan que en Brasil hay "mejores condiciones de vida", pero ésta no es su área, y no posee las facilidades para su alimentación, ni ríos como el suyo en el Delta, ni hay palmas de moriche para sacar su materia prima tan necesaria para sus artesanías y hasta para alimentarse, ni se vive en palafitos como en su Delta, ni hay gusanos de moriche para su alimentación diaria, pero saben -por diversas informaciones- que allá, existe una fundación o "gente de buen corazón" que los acoge, les da de comer y los alberga y les ofrece una cama para dormir, medicamentos para sus hijos, educación, 
que aprenden el idioma y, además, pueden vender sus artesanías, recibir su moneda nacional y convertirla en dólares para regresar a Venezuela. Ésta es, en síntesis una oferta tentadora que ha sido experimentada ya por varios warao, con quienes hemos conversado y así, no consideramos que sea un éxodo masivo y definitivo, sino, el de unos jóvenes especialmente, visionarios que se han marchado con sus hijos, esposas, suegras, etc., para buscar un futuro temporal, pero también algunos, se llevan a sus padres, abuelos tíos, tías niños, y familiares cercanos por su situación crítica y por conservar su ayuda familiar.

Analizamos nosotros, que se van con la esperanza y con el fin de volver a sus caños tradicionales, pero con dinero fuerte que les pueda permitir pasar una temporada. No obstante, ya han conocido el camino y pueden volver cuantas veces lo deseen, yéndose en autobús, desde San Félix, Maturín o Ciudad Bolívar, llegar a La Línea, seguir a Pacaraima, Boa Vista o Manaos. Y si pudieran, podrían llegar a través de varios años hasta el Delta el Gran Río Amazonas con la ilusión de estar nuevamente en su ambiente de un Delta que, aunque no sea el de ellos -que por miles de años lo ha sido-, sería lo más óptimo para volver a estar en un ambiente similar al de sus orígenes.

Lamentamos que ahora, en este momento estemos tan lejos de Venezuela, ya que ahora participamos de una investigación de largo plazo con pueblos indígenas de Centroamérica, igual en áreas de selva y también con indígenas desplazados por los intereses capitalistas que están en todas las regiones indígenas de Abya Yala. Para abordar este ensayo hemos tenido que indagar, llamar a nuestros colegas en Venezuela y hablar inclusive con algunos amigos y cultores warao con quienes hemos trabajado muchas veces en nuestras investigaciones de campo, entre ellos, Héctor Figueroa, Nayibeth Romero, Maury Márquez, Minerva Vitti, el Maestro Esteban Emilio Mosonyi, Carmen Medrano (2005), la señora Higinia, Maigualida Rivas, ChernoiiJaratamii Joreke (Rafael Enrique Cortez), el maestro Omar González Ñañez, (quien recientemente se marchó de este plano terrenal) y tantas personas más, inclusive warao que viven y siguen viviendo en el Delta, o que han ido y han vuelto del Brasil.

También leímos los materiales que ha publicado UNHCR-ACNUR en Brasil sobre los pueblos indígenas del Sur de Venezuela, como los eñepa o panare. Hemos leído sobre la mención que se hace de los pemón, que también son de Venezuela, aunque los haya en Roraima, Brasil, pero sobre todo, hemos detallado lo que se informa de los warao.

Se afirma que entre los dos pueblos, eñepa o panare (los mismos con dos nombres), y los warao, entre ambos suman unos 4.000, pero no se especifica más. Entonces, si asumimos que hay esta cantidad, por lo menos, debería haber 2.000 de cada pueblo indígena. Dato que puede ser verdad dado que existen aproximadamente, unos 49.000 warao, de lengua independiente, ubicados, como sabemos, entre el estado Delta Amacuro, Monagas y Bolívar. (Censo,lamentablemente tardío, del 2011), pero fundamentalmente ubicados en su mayoría en cuatro municipios de Delta del Orinoco: Casacoima, Pedernales, Tucupita y Antonio Díaz, siendo que en solo este último hay 325 comunidades y en todo el Delta, unos 3.000 caños poblados que forman el pueblo warao, y por supuesto, los criollos que también son parte del estado Delta Amacuro ${ }^{3}$.

Luego, existen aproximadamente unos 34.000 eñepa o panare, que habitan en el municipio Cedeño, ubicado en el extremo oeste del estado Bolívar, al norte del estado Amazonas, de Venezuela. Hablan el idioma panare perteneciente al tronco lingüístico karibe. Ocupan un territorio de unos $20.000 \mathrm{~km}^{2}$ ubicado en la parte noroccidental del estado Bolívar, con un pequeño enclave en el estado Amazonas, Serranía del Alto Cuchivero y en el Valle de Cayamá, donde conviven con los indígenas hoti y se extienden por la región de los ríos Cuchivero, Guaniamo y Suapure, lugares que hoy están minados por la fiebre del oro de criollos y algunos garimpeiros.

Sin embargo, quisiéramos conocer más de cerca esos datos de los 4.000 indígenas procedentes de Venezuela refugiados en Brasil en los lugares mencionados, como Roraima,

3 N.A. Pensamos que quizá por algún error histórico el estado Delta Amacuro lleva el nombre del río Amacuro y no el del Orinoco, río éste que es el que realmente forma el Gran Delta, aunque también esté en dicha formación fluvial el río Amacuro, de menor caudal. 
Amazonas, Pará y Piauí, donde se afirma se encuentra la mayoría de estas poblaciones, y así como en otros estados del país y se especifica que permanecen en los refugios o albergues Pintolândia y Janokoida, en Roraima. Pensamos que este número no es tan probable y quizás, sí, sean todos los migrantes incluyendo criollos venezolanos. También se nos ha informado que un grupo significativo inició un éxodo hacia tierras andinas de Argentina, (posiblemente Bariloche).

Valoramos altamente la dedicación desinteresada, humanitaria y altruista de las ayudas que reciben nuestros indígenas (y criollos) que han sido asistidos como "refugiados". Además, valorados por la Iglesia, en la comunidad Bautista de Pacaraima, en este caso, de manera directa por el pastor Gideão y Sra. Sandra, ambos bautistas. Luego, a la Fraternidad de la Federación Humanitaria Internacional, en el marco del R4V, respuesta a venezolanos, Plataforma Regional de Coordinación Interagencial para Refugiados y Migrantes de Venezuela, haciendo, todos ellos una labor de doctrina, alfabetización, cuidados de la salud, enseñanza de un idioma nuevo, darles albergue, alimentación y concretando su ayuda, en la redacción de una Cartilla muy significativa en cuatro idiomas: portugués, castellano, warao y panare, con ayuda de hablantes indígenas como, Abigail Reinosa (quien además elabora los diseños), Marcela Sánchez, Griselia Báez, Alberto Conejero y Otilia Alicia Aranguren. Es un gran ejemplo de buena voluntad. El nombre de la útil cartilla en 28 páginas es la siguiente: Comunicación sobre Salud Indígena Warao y Eñepa. Folleto multilingüe ${ }^{4}$.

Muchos documentos se han escrito sobre esta situación de los migrantes hacia Brasil, cientos de noticias en canales internacionales, como BBC News, algunos manifiestan dolor por la situación, otros expresan preocupación y algunos otros más humanistas, abogan por los derechos de los migrantes, y gran cantidad de ellos, los apoyan. Así, sacerdotes como Jesús López de Bobadilla, asume una responsabilidad humana como es bridarles café con pan a más de 1.700 personas, indígenas y no indígenas, y un señor de buena voluntad como lo es Lourival Ferreira, presidente del Sindicato de Trabajadores de la Construcción Civil de Boa Vista, ha ayudado a orientar a los migrantes venezolanos a la conformación de una Asociación de Migrantes en Boa Vista y, por su buena voluntad de ayudar con su energía y orientación, ha sido amenazado por sus mismos paisanos, ya que se ha desatado también la xenofobia y la exclusión de estos migrantes en situación de crisis, como también ha ocurrido en otros países entre ellos Colombia, Perú o Ecuador muy especialmente, pero que nunca se había desatado en un país como Brasil, con el cual, a través de la historia siempre Venezuela ha mantenido muy buenas relaciones, tanto es así que hay aún mucho respeto por la obra histórica de Bolívar y se han mantenido muy buenas relaciones políticas y económicas. Pero en momentos de crisis se agrandan los problemas, como agredir "a los venezolanos", quemarle sus improvisadas carpas. Pedir su expulsión de parte de pobladores enardecidos e inclusive solicitar oficialmente represión contra ellos. Sin embargo, ha habido -y nosotros lo agradecemos- muchas personas de buena voluntad que han manifestado públicamente su apoyo hacia ellos como es el caso del ministro del Gabinete de Seguridad Institucional, Sergio Etchegoyen, quien negó una petición de desalojo y dijo que la posibilidad era "impensable e ilegal" y afirmó: "Tenemos que cumplir la ley. La ley brasileña de inmigración determina la acogida de refugiados e inmigrantes en esa situación".

Otra declaración importante sobre el tema que estamos tratando es la siguiente:

Para el jefe de la oficina de ACNUR en Pacaraima, Rafael Levy, además de las personas en tránsito a través de la frontera, uno de los mayores desafíos a los que se enfrenta es apoyar a las personas sin hogar que por alguna razón han decidido quedarse en la ciudad. "La creación de redes es fundamental y la Iglesia Bautista de Pacaraima es nuestro socio principal en este sentido. Con su trabajo y su red de iglesias, apoyan a las personas para reconstruir sus vidas e integrarse en Brasil", señala Levy. Es una declaración satisfactoria principalmente para nuestros migrantes y para la tranquilidad de todo el país, como lo es Venezuela, que también a lo largo de más de doscientos años, ha sido igualmente, un país de migrantes.

4 Fuente: Alto Comisionado de las Naciones Unidas para los refugiados (ACNUR), 27 de abril 2020. País, BrasilVenezuela. Temas: COVID 19/. Derecho a la salud/ Personas Migrantes/ Personas Refugiadas/ Pueblos Indígenas / Salud Pública/. (Disponible en: https://www.refworld.org.es/docid/5ea75ef44.html. Acceso: 19 de mayo de 2020)

EntreRios - Revista do PPGANT -UFPI -Teresina • Vol. 3, n. 2 (2020) 
Las informaciones de prensa del Brasil, tanto de periodistas, de fotógrafos, de antropólogos, de autoridades de migración, alcaldes, médicos, enfermeros, pastores, buenos ciudadanos, entre otros, las vemos con mucho respeto y con datos, algunos no tan exactos, pero hacen parte del análisis general de esta situación de emergencia, que además, de la migración en masa, se suma el problema de la pandemia del COVID-19, y solo para destacar estas afirmaciones, destacamos algunos tips, específicamente, con fines ilustrativos:

1. En relación al refugio de venezolanos en los últimos tres años, según la ONU, 2,3 millones de venezolanos dejaron el país, huyendo sobre todo de la falta de alimentos y medicamentos en una nación donde una maleta llena de dinero apenas alcanza para comprar un pollo. Sólo en el primer semestre de este año, más de 56.740 venezolanos solicitaron refugio o residencia temporal en Brasil. En ese mismo periodo, más de 16.000 venezolanos llegaron a Roraima pidiendo asilo, un $20 \%$ más que en todo el 2017.

2. Sobre Crisis migratoria de Venezuela, la tensión en Pacaraima, la ciudad de Brasil donde atacaron a migrantes venezolanos ${ }^{6}$.

3. En Manaus, el paciente más joven es un bebé de dos meses y el resultado del diagnóstico tardó 11 días en salir. Los pueblos warao buscan apoyo en las calles de Manaos ${ }^{6}$.

4. Izabel Santos y Vivianny Matos (2020), del Amazonas Real, con datos muy ilustrativos: Manaus (AM) y Belém (PA) - Los estados de Amazonas y Pará anunciaron las primeras notificaciones del nuevo coronavirus en los migrantes venezolanos del grupo étnico warao. Este miércoles (16), en Belém, un hombre de 64 años murió durante el tratamiento de COVID-19 en el Hospital Municipal de la Retaguardia Dom Vicente Zico. Dos personas más tienen el virus, pero de forma aislada. En Manaos, un bebé de dos meses fue infectado e ingresó en el Hospital y Sala de Emergencias Delphina Aziz, en la parte norte de la capital amazónica. Su estado de salud es estable.

La muerte del indígena warao fue reportada en vivo en internet por el alcalde de Belém, Zenaldo Coutinho (PSDB). "Tuvimos dos casos más de coronavirus entre los warao venezolanos. PMB (Ayuntamiento de Belém) está transfiriendo a unas 50 personas, para abandonar el grupo que tuvo contacto de forma aislada. Para preservarlos a ellos y a otros", dijo el alcalde.

El bebé warao nació el 28 de enero en Manaos. Él, su madre, su padre y otros seis hermanos vivían en un refugio con más de 500 migrantes alojados, en la parte norte de la capital amazónica. El primer síntoma presentado fue un resfriado el 2 de abril, cuando el recién nacido ingresó en el Hospital Pronto Socorro da Criança, en el distrito de la ciudad, lado oeste de Manaos. La prueba, que confirmó el nuevo coronavirus, salió el 13 de abril, 11 días después de la hospitalización. A la confirmación del caso, el bebé fue trasladado en las primeras horas del martes (14) al Hospital y Sala de Emergencias Delphina Aziz, en el norte de la ciudad, que es la unidad de referencia para el tratamiento de COVID-19 en el estado. El padre del niño, que está aislado, y los otros niños fueron reubicados en un nuevo refugio en el lado oeste de la ciudad. El Ayuntamiento de Manaos, que reveló el caso a la prensa, no dijo por qué la prueba del nuevo coronavirus en el bebé tardó 11 días en salir. En un comunicado, dijo que "dado que el hospital [Hospital da Criança] solo cobró la prueba de COVID-19 después de 11 días de la admisión de la mujer indígena a la unidad, no es posible confirmar si la infección estaba en el hospital o en el refugio donde vivía la familia".

Estas aclaratorias que se afirman, las analizamos con mucha responsabilidad y con esta explicación siguiente se confirma la seriedad de cómo atendieron al niño, a su madre y a su familia. La directora ejecutiva de FVS, Rosemary Pinto, justificó el retraso en el diagnóstico del bebé warao. Ella dijo que la sospecha surgió después de una investigación realizada por el Hospital de Niños de la Zona Oeste y la Sala de Emergencias. "Como es un niño indígena, tiene varias patologías. Este niño fue hospitalizado por un tiempo hasta que los médicos consideraron la posibilidad de la hipótesis diagnóstica de Covid-19. Cuando se identificó al niño con esta posibilidad, se activó Lacen, se realizó la recolección y se realizó el diagnóstico. Este período de 11 días fue el momento en que la unidad [hospital], entre tantas patologías presentadas, sospechaba de Covid-19", dijo el director.

5 Relatado en Noticias por BBC News, a través de Júlia Díaz Carneiro.

6 Con Foto de Bruno Kelly / Amazônia Real. 
Hay muchas informaciones referentes a los warao migrantes, y nos brindan material para poder hacer un gran trabajo de investigación y análisis de los datos, muchos de ellos infaltables, pero lamentablemente, tenemos que reducir esta participación y, en este caso, solo vamos a comentar unos tres testimonios más para concluir.

5. Sandro Santos, antropólogo de la Universidad Federal de Amazonas (UFAM), explica que la situación de los migrantes, en general, es aún más delicada debido a la pandemia. “Espacios como Caritas y Pastoral do Migrante han reducido en gran medida su capacidad de servicio como efecto secundario de la lucha contra los virus. Si el servicio ya era bastante limitado, ahora con la suspensión de los servicios de documentación, las referencias a cursos de capacitación y la reducción de las donaciones, la situación de las personas en la calle, o incluso en los refugios, debe haber empeorado mucho ", afirma. Y continúa diciendo que aquellos que duermen en refugios o pasan la noche en las tiendas de la estación de autobuses a menudo necesitan recorrer la ciudad durante el día. El antropólogo llama la atención sobre la situación de los indígenas warao: "Son un caso aún más especial, ya que tienen mucha desnutrición y viajan con ancianos y niños", destaca (SANTOS \& MATOS, 2020).

Sandro señala la necesidad de un enfoque intercultural más cuidadoso durante la pandemia. "Covid-19, desde un punto de vista indígena, puede considerarse como una 'enfermedad blanca'. Pero, como tantas enfermedades respiratorias que históricamente han promovido muertes, son particularmente vulnerables a las enfermedades respiratorias y no existe un chamanismo que cure la enfermedad blanca. El chamanismo cura enfermedades previamente conocidas", confirma $^{7}$ (SANTOS \& MATOS, 2020).

Además, algunos hábitos pueden facilitar la transmisión de la enfermedad, como compartir utensilios, vasos, cubiertos y calabazas. Además, la costumbre de pedir dinero en la calle, que se considera un trabajo para los warao. "Es parte de la dinámica diaria, especialmente para las mujeres, salir a recolectar dinero. Dondequiera que se lleve a estas personas, no aceptarán estar en casa. Les falta este dinero, no solo para el mantenimiento diario aquí, sino para enviarlo a Venezuela", destaca. "Una cosa es estar en la comunidad misma, otra es, la gente indígena dispersa en la ciudad, involucrada con la dinámica de una ciudad. Los warao ya han estado lejos de sus hogares por algún tiempo" (SANTOS \& MATOS, 2020).

Entre los warao recibidos en Manaos se encuentran maestros indígenas y también trabajadores de la salud. No todos saben leer y escribir, pero están adaptados porque han vivido en centros urbanos durante generaciones. En el apogeo del gobierno de Hugo Chávez, ex presidente de Venezuela, tenían escuelas y atención médica. “Estos maestros y trabajadores de la salud son los principales líderes en esta aventura en Brasil, ya que pueden hablar español y aprender portugués con mayor facilidad". Y agrega: "es importante señalar que los venezolanos, en general, son una población, en promedio, educados...así, No creo que les sea difícil entender la gravedad de la situación. El dilema es la falta de vivienda y de acceso a los recursos básicos. Ahora, muchos venezolanos están buscando formas de regresar a su país. La gran atracción de estar en Brasil era la posibilidad de trabajar, ganar dinero y comprar comida. Con las oportunidades de trabajo reducidas debido a las medidas para suprimir Covid-19, las dificultades económicas están estimulando los movimientos para regresar a Venezuela ${ }^{8 \prime \prime}$, concluye el antropólogo Sandro Santos, de la UFAM (SANTOS \& MATOS, 2020).

Un análisis muy serio, severo y prometedor, tan visionario, que ya se está comprobando pues hay muchos warao que ya han regresado a sus amados caños del Delta del Orinoco y se han dirigido al municipio Antonio Díaz.

6. Debemos destacar aquí, el papel objetivo y a la vez humano que se ha manifestado en el portal periodístico amazoniareal.com.br, que aboga por derechos y tratamiento adecuado para los indígenas warao migrantes, sus necesidades de salud, urgencia de dinero y premura de albergue y alimentación para familias indígenas que por diversas razones hoy están en territorio brasileño.

7 Entendemos que "enfermedad blanca" proviene de la cultura criolla, no indígena.

8 T.A. Hemos subrayado esta parte ya que tal aseveración nos da una pista para afirmar su posible retorno a los caños del Delta del Orinoco. 
Por último considero obligatorio mencionar el documento preparado por ACNUR (2019) publicado como Nota Informativa para municipios sobre la llegada espontánea de población venezolana incluyendo indígenas. En este trabajo de 20 páginas, muy ilustrativo, nos informamos de otros trabajos serios sobre los warao en Brasil como el proyecto de tesis doctoral en Antropología Social de Marlise Rosa (2019) cuyo título es La movilidad de los Warao y los desafíos para la gestión de una población en tránsito.

Con todo lo descrito anteriormente sobre estas nobles personas e instituciones, no dudamos que muchos de los allegados se sientan atraídos por sus atenciones y ayudas humanitarias, sobre todo, en momentos largos ya que poseen un "país" que a pesar de todo hace esfuerzos por atender a las poblaciones indígenas, cuyos espacios aislados están llenos dificultades por la infinidad de problemas que su país atraviesa. Aún a pesar de todo, San Francisco de Guayo (Delta del Orinoco) posee un hospital con todos los requerimientos para atender cualquier enfermedad, y allí, casi el 100\% de sus habitantes son warao atendiendo, además, a 325 comunidades fluviales. Sin embargo, no podemos negar que hay insuficiencias por diversos conflictos, las mismas que hacen producir un comportamiento de aceptación de ofertas más atractivas, aun con todas las dificultades y también surgen las inadecuadas conductas sociales que nunca se habían visto entre los pueblos indígenas, pues sabemos que hoy existe el robo, el abuso, la agresión y muchos warao han tenido que huir de sus comunidades. Algunos para Tucupita, San Félix, Maturín, Ciudad Bolívar, Tumeremo, El Callao, Caracas, ya que, como hemos explicado, vienen padeciendo problemas desde hace más de 50 años, sobre todo, los que se han exiliado de sus comunidades fluviales por diversas razones y así, sus comportamientos ya no son componentes integrales en la relación de familia y, en circunstancias especiales han aprendido con los criollos o por necesidad, hábitos inadecuados para vivir.

Además, no podemos ignorar ni poner en el exilio que Venezuela, en este momento atraviesa problemas muy severos por el bloqueo económico, a tal grado que no puede procesar ni siquiera el petróleo crudo del subsuelo para convertirlo en gasolina y aceite, que se vende asimismo, como el producto más barato del mundo, ya que un taque de gasolina, puede costar una bagatela, (aún ahora, después que llegó de Irán), pero una taza de café puede costar lo que valen 2.000 litros de gasolina, precios que son manejados por el Estado, pero no el café. Así, Venezuela no puede producir los insumos para el refinamiento que eran importados y asimismo, una gran cantidad de productos necesarios para la vida y también y fundamentalmente las medicinas, los repuestos, materiales de construcción y esencialmente gran parte de la alimentación ineludible para los 30 millones de habitantes. Esta es una realidad que no puede negarse. (Actualmente ha recibido insumos para el procesamiento del petróleo pesado, gasolina refinada y productos alimenticios de Irán, pero según los medios, ya se agotaron).

Sin embargo, no todas las informaciones que se destacan sobre Pacaraima, en el norte del Brasil, son tan exactas. A veces, son poco explicativas, como esta de "José, de 50 años", que fue uno de los primeros en ser acogidos por la iglesia. El venezolano que llegó a Pacaraima en julio de 2018 pasó más de un mes en la calle hasta que lo atendieron. “Tuve que dejar a mi esposa y mis dos hijos y viajar 16 horas en autobús desde Maturín para llegar aquí. Estaba muy débil y desnutrido, pero hoy soy fuerte y ayudo en lo que el pastor y Sandra necesitan", dice José, quien hoy es uno de los líderes del grupo de 16 voluntarios venezolanos que ayudan a la pareja a hacerse cargo del proyecto.

Información de prensa en las redes. Pero, allí no se aclara si el Sr. José es warao, eñepa o criollo. Sí sabemos de un indígena warao de nombre Euligio Báez que llegó al refugio con esposa y cinco hijos y se declaró refugiado ya que afirmó que lo iban a matar. También declaró que tres de sus familiares eran perseguidos con el mismo fin, pero no explica los detalles que quienes lo conocen saben del comportamiento de algunos de sus hijos. Es decir, se desconocen los pormenores y así, la interpretación de estos hechos puede ser inadecuada y confundir o generalizar estas escenas, sobre todo en pueblos indígenas que, como los warao, son gente muy pacífica.

Otra información de las redes es la de Sandra, quien también trabaja con la recepción de menores que llegan a la ciudad, recuerda que el proyecto guía a las familias a participar en la es- 
-trategia de reubicación interna, una iniciativa del Gobierno Federal apoyada por agencias de la ONU y la sociedad civil para la reubicación voluntaria de refugiados y migrantes a otros estados brasileños. "Ya hemos ayudado a más de mil venezolanos a ser reubicados a otros estados. Esto es importante para que podamos seguir recibiendo a los que llegan aquí a Pacaraima", dice Sandra.

En esta información, no se indica si esas 1.000 personas son warao, eñepa o criollos. Por tal razón, sería necesario saber el dato exacto de warao, pues sí sabemos que hay miles de criollos que han salido al exterior a diversos países, como Colombia, Ecuador Perú, Chile y Panamá muy especialmente, y las mismas informaciones que se difunden en Brasil, como en otros países, es decir, lo más común, es que 4,2 millones de venezolanos han salido del país por la crisis política que atraviesa Venezuela, etc. Ahora, ya no es sólo por la crisis política y social, ahora se une la crisis mundial de la pandemia del COVID-19, con lo cual se ha desatado la xenofobia, desprecio, miedo y exclusión. Y así, son despreciados los migrantes venezolanos en países como Perú, Colombia y Ecuador y, de esta manera, ahora muchos o casi todos de estos venezolanos, están clamando por volver con urgencia a su patria, que algunos de esos migrantes han muerto con la pandemia y simplemente fueron sepultados en entierros colectivos.

Favorablemente en el norte del Brasil, aunque se haya muerto ya un migrante warao de 64 años y se destaca que un niño también se contagió, fue atendido de manera prioritaria, y asimismo, algunas mujeres embarazadas que se fueron, han dado a luz allá y según descripciones demostradas antes, han sido atendidas debidamente. Otras informaciones orales, dicen que se han muerto ya, cuatro miembros de los migrantes warao, pero no hay datos exactos.

Volviendo a Pacaraima y a la atención del migrante, necesario es destacar que son muy significativos los proyectos que allí se aplican y así se afirma: Este importante proyecto solo fue posible gracias al apoyo de la Unión Europea que, desde 2018, ha estado invirtiendo en fortalecer la respuesta a los venezolanos en la región norte de Brasil con proyectos que promueven la protección de las poblaciones más vulnerables y la convivencia pacífica con la comunidad local. En 2019, la "Operación Acogida" también comenzó a colaborar con esta actividad ofreciendo loncheras diarias y permitiendo la extensión y continuidad de esta acción y proporcionando mejores condiciones para cientos de personas que llegan de Venezuela.

\section{A manera de epílogo. Los pueblos indígenas del mundo tienen derecho a su libre determinación}

Con todo lo anterior queremos dejar claro que no pretendemos ignorar ni minimizar el hecho real de la migración masiva de venezolanos en esta crisis que padecemos desde hace varios años, sin embargo, no estamos seguros que 2.000 o 4.000 indígenas warao se hayan marchado en gran éxodo para las regiones del norte del Brasil. En este sentido, para el día 25 de mayo de 2020, poseemos la siguiente información:

“Saludos Dr. Ronny. Por problemas de la electricidad, en mi sector por más de 38
horas sin este servicio, no le había respondido. Debo ser muy claro con usted y
responsable con el tema de los warao en el extranjero. En este momento está
trabajando en una comisión de servicio el Licdo. Arturo, es de la comunidad de
Araguiamujo, un hombre muy preparado académicamente, él escuchó su mensaje
de voz, y me dice que es difícil que los waraos se queden en Guyana, Trinidad y
Brasil. Allá, están pasando necesidades igual que aquí en el estado, la única
diferencia es que, con lo poco que ellos trabajan, esto les permite comprar
alimentos. Por lo demás muchos de ellos viven en la calle. Con el aidamo9 de un
pueblo, Elías Pérez de Mariusa emigraron hacia Brasil más de 200 de ellos, y se
encuentran en Belén de Para. Los waraos si retornarán al Delta pero consideramos
que no será en este año, por las condiciones que usted conoce del Delta del
Orinoco, Dr. Ronny usted conoce la situación en la que se encuentran los waraos

9 Jefe tradicional de cada pueblo warao, se llama Aidamo Arotu. 
en el estado con esta pandemia están más abandonadas las comunidades, por la falta de combustible, aceite, y alimentos, le reitero nuestra opinión es que los waraos no retornaran al país todos, tal es el caso de los waraos de Mariusa.

Gracias por su preocupación y atención a nuestros pueblos aborígenes, cuente usted con mi apoyo incondicional. Nota lo que usted envíe le daré respuesta mañana, el toque de queda comienza a las $12 \mathrm{am}$ ".

Respuesta del colega antropólogo que trabaja con los warao en el Delta del Orinoco: Rafael Enrique Cortez, cuyo nombre indígena que aparece en su firma y en su cédula es, Chernoiijaratamii-joreke, del pueblo étnico warekena. Pero es además, hablante warao.

La otra información del mismo día, es la enviada por el profesor Héctor Figueroa, cultor e investigador de la cultura warao del estado Delta Amacuro, y es la siguiente:

"Este fin de semana hablé con varios warao en diversas comunidades, y si me han confirmado que muchos warao de diversas partes se han ido para Brasil en pequeños grupos, desde hace unos 15 años empezaron poco a poco a irse. Esta es una información de Junior Palacios. Emilio Alexis Valenzuela, afirma que se van por negocios y allá tienen refugios o abrigos (Subrayado nuestro) y les dan de comer. A los refugios los warao les llaman Kauba-noko, (lugar para dormir). Argenia Centeno, informa que estuvo allá y que, como es maestra, hasta dictó unos talleres, pero se regresó. Ellos mismos afirman que hay dirigentes warao, que son líderes actuales, no aidamo arotu, como los tradicionales, sino que son políticos, como es el caso del Sr. Teobaldo Zapata de la comunidad España, del municipio Antonio Díaz, que incita a los warao para este viaje y los organiza en autobuses desde San Félix, en el estado Bolívar para realizar la travesía y él se encarga de todos los arreglos correspondientes para irse al Brasil. Afirman que él lo hace por negocio ya que un warao no puede salir del Delta del Orinoco si no tiene su tarjeta que lo identifica como indígena warao, sin embargo, igual salen, porque muchos warao, han perdido su tarjeta que los identifica y el Sr. Zapata se encarga de este detalle. Ellos afirman que ahora hay warao en Belén do Para, Manaos, Boa Vista y Pernambuco."

Y este mensaje del día 26 de mayo de 2020 desde el Delta del Orinoco, del antropólogo citado Chernoii-jaratamii-joreke, en su lengua warekena:

“Saludos Dr. Ronny, le explico (en relación a los nombres criollos de los warao) Es el mismo caso de los waraos, los criollos, los jotaraos, le ponen el nombre que más les parezca a ellos o el que les conviene. En mi caso pasó igual, los funcionarios de la ONIDEX (extranjería), en el año 1968 fue cuando saqué por primera vez dicho documento, el número de cédula de mi madre comienza por 3 millones y el mío comienza por 1 millón, y me pusieron por nombre Rafael Enrique Cortez. (Pero al hacer el censo indígena, yo firmé la planilla y allí coloqué mi nombre indígena: Chernoii- jaratamii-joreke, nombre que tienen que ver con mi madre que era warekena. NOTA APARTE DEL MISMO CHAT: El Prof. Arturo González de la étnica warao hoy vino con su esposa (de Brasil) y ellos me están explicando que ya tienen información de la emigración de más 1.056 warao que se encuentran entre Brasil, Trinidad y Guayana. En este último país se encuentran más de 180 hermanos warao. Aclarada mi identidad y otros datos sobre los waraos, en línea y a sus órdenes, Dr. Ronny"10.

10 N.A. Conociendo de nuestra parte la cultura warao, le preguntamos al colega antropólogo de la etnia warekena, de Venezuela, por qué hoy día hay tantos warao con nombres castellanos, en los caños, cuando esto no ha sido lo más común y aunque los sacerdotes desde su existencia en el Delta, hace más de 200 años, los hayan bautizado con nombres castellanos, ellos normalmente en sus caños usan sus propios nombres indígenas. Así, en el chat anterior él 
Por último, una información agregada que nos llegó hoy martes 11 de agosto del mismo luchador social que vive en Tucupita, capital del Estado Delta Amacuro y que experimenta día a día la problemática de los warao y que siente sus complicaciones como indígena amazónico que es:

"Saludo Dr. Ronny, quiero plantearle una situación muy delicada... debo informarle de la visita del aidamo (jefe tradicional) de la comunidad de Boca de Latal, Franklin Rojas, él estuvo por mi casa, y me explico la situación que están padeciendo en el paseo Manamo, (Calle de la capital Tucupita, que corre por la orilla del rio Orinoco en su brazo, de nombre Manamo). Allí se encuentran él y toda la comunidad, sin ninguna protección del estado para los niños adultos ni mucho menos para los que tienen alguna discapacidad, y ahora con esta pandemia ellos se encuentran en riesgo absoluto. Me decía que él le envió una misiva a la gobernadora y a la alcaldesa del municipio capital y ellas le participaron por separado que no tenían ni gasolina, ni trenes (atarrayas, redes para pescar), ni anzuelos, ni mucho menos bolsas de alimentos para ellos, que más bien él no tenía por qué estar aquí en Tucupita...Él explica que allá en su comunidad, donde vive está inundada y no hay ningún tipo de siembra por el clima lluvioso, por lo tanto no hay nada que comer... Como puede verlo... estos señores gobernantes utilizan a los warao solamente para sus beneficios, cuando están en campaña y en este momento el estado venezolano no cuenta ni con su principal recurso, que es el petróleo... que es el que lo da todo... es lamentable esta situación en la que han caído nuestros pueblos, pero más aún, en las comunidades indígenas. Hoy los warao padecen de tuberculosis, dengue, paludismo, sida, y ahora del covid-19"...

Luego, Chernoii, como indígena Warekena y hablante del warao, hace una crítica muy severa: “Ud. puede comprobarlo, al no ser atendidos por el estado, (se refiere al Estado Delta Amacuro)... no sé qué será peor, la pandemia, o las acciones negativas de estos mal llamados revolucionarios". ... Muy atentamente Chernoii, Rafael Enrique Cortés.

Estas informaciones recientes y directas, son bastante trágicas y por tanto, no dudamos que muchos warao, al verse en estas y otras situaciones, deciden migrar. Con todo ello, afirmamos que sí es demostrable que ha habido un éxodo para las regiones del norte de Brasil que tal vez haya sido de grupos de familia, pero no manera masiva. Sin embargo, dejaremos espacio para abonar informaciones más nuevas pero en todo caso, penamos que aún no ha habido tiempo para la conformación de un pueblo allá en territorio brasileño. Tal vez se diseminen por diversos rumbos. No sabemos hasta ahora. En este momento, al parecer, no tenemos noticias de que han formado un pueblo, o un ja-noko, su lugar de permanencia, quizás buscarán un gran río donde haya abundancia de peces, pero quizás, les haga falta el moriche y si hacen ese lugar, deseáramos que sea bien visto por el pueblo brasileño y especialmente por los indígenas que vivan en el área dónde ellos deseen asentarse, y que las autoridades del Brasil también sean benevolentes respecto a este éxodo que hoy sí lo consideramos significativo.

También sabemos de las luchas de los pueblos indígenas del Brasil por defender sus territorios, derechos humanos, derechos a estudiar en instituciones de nivel universitario y también, por último, que hay aún indígenas no contactados, sobre quienes se ha propuesto la catequización, para que pasen a formar parte de una sociedad controlada. Esta propuesta está negada desde su origen por los profesionales comprometidos con los pueblos indígenas del Brasil, no solamente antropólogos, sino por científicos sociales y humanos y antropolingüístas en general. Quizás, por la consistencia misma del pueblo warao y su cultura, estos sean tratados con franca aceptación, así lo esperamos y desde ya lo agradecemos.

aclara nuestra interrogante, redunda en las formas de la migración, salen con nombres criollos y este cambio puede influenciar la confusión entre criollos e indígenas. Además Chernoii aclara que ya posee un incipiente censo de 1.056 warao en tres países y que 180 de ellos están en Guayana, pues es natural que entre Brasil y Trinidad pueda haber 876 y de estos suponemos que la mayoría esté en Brasil. 
Nosotros consideramos que los pueblos indígenas del mundo tienen derecho a su libre determinación, como están definidos ya sus derechos en las leyes de los pueblos indígenas del mundo. Los mismos que han sido aprobados a través del Convenio 169 de la OIT sobre Pueblos Indígenas y Tribales y la Declaración de las Naciones Unidas sobre los Derechos de los Pueblos Indígenas. Para más especificidad, en Venezuela, en la Constitución vigente de la República Bolivariana de Venezuela, poseen todo un capítulo, el VIII, con ocho artículos y sus incisos, además, sus idiomas todos son oficiales en las regiones del país en que se hablen, he aquí, un resumen:

“De los Derechos de los pueblos indígenas Artículo119. El Estado reconocerá la existencia de los pueblos y comunidades indígenas, su organización social, política y económica, sus culturas, usos y costumbres, idiomas y religiones, así como su hábitat y derechos originarios sobre las tierras que ancestral y tradicionalmente ocupan y que son necesarias para desarrollar y garantizar sus formas de vida.

Artículo 120. El aprovechamiento de los recursos naturales en los hábitats indígenas por parte del Estado se hará sin lesionar la integridad cultural, social y económica de los mismos e, igualmente, está sujeto a previa información y consulta a las comunidades indígenas respectivas.

Artículo 121. Los pueblos indígenas tienen derecho a mantener y desarrollar su identidad étnica y cultural, cosmovisión, valores, espiritualidad y sus lugares sagrados y de culto. El Estado fomentará la valoración y difusión de las manifestaciones culturales de los pueblos indígenas, los cuales tienen derecho a una educación propia y a un régimen educativo de carácter intercultural y bilingüe, atendiendo a sus particularidades socioculturales, valores y tradiciones.

Artículo 122. Los pueblos indígenas tienen derecho a una salud integral que considere sus prácticas y culturas. El Estado reconocerá su medicina tradicional y las terapias complementarias, con sujeción a principios bioéticos.

Artículo 123. Los pueblos indígenas tienen derecho a mantener y promover sus propias prácticas económicas basadas en la reciprocidad, la solidaridad y el intercambio; sus actividades productivas tradicionales, su participación en la economía nacional y a definir sus prioridades.

Artículo 124. Se garantiza y protege la propiedad intelectual colectiva de los conocimientos, tecnologías e innovaciones de los pueblos indígenas. Toda actividad relacionada con los recursos genéticos y los conocimientos asociados a los mismos perseguirán beneficios colectivos. Se prohíbe el registro de patentes sobre estos recursos y conocimientos ancestrales.

Artículo 125. Los pueblos indígenas tienen derecho a la participación política. El Estado garantizará la representación indígena en la Asamblea Nacional y en los cuerpos deliberantes de las entidades federales y locales con población indígena, conforme a la ley.

Artículo 126. Los pueblos indígenas, como culturas de raíces ancestrales, forman parte de la Nación, del Estado y del pueblo venezolano como único, soberano e indivisible."

Desde nuestra posición, comprometidos con los pueblos indígenas, agradecemos infinitamente al pueblo del Brasil, a sus autoridades, a sus organizaciones y ONG's, a sus iglesias evangélicas o católicas su gran ayuda con los miembros de este pueblo tan originario que tiene más de 5.000 años en el área, que aún conservan su cultura tradicional, sus chamanes, sus parteras o comadronas, sus instrumentos musicales, su Seke-Seke o violín con su mito de creación y el relato de Kobe y Naku. Sus narraciones, cuentos o mitos de origen, sus celebraciones a sus ancestros como el Nahanamo, sus bellas artesanías, y sobre todo, su idioma, que es de lo más hermoso, sonoro, radiante y simbólico, en el cual, muchas de sus palabras poseen significados metafóricos, y basta citar, algunas de ellas por ahora, como lo es partera o comadrona, ellos le llaman Diawara mojo namina, que significa "Manos sabias que producen el nacimiento". Para expresar el concepto alma dicen mejokoji, que significa "el sol del pecho". Amigo lo expresan como Ma-jokaraisa, que quiere decir "mi otro corazón". Olvidar lo expresan con la palabra emonikitane, que quiere decir "perdonar".

Asimismo, los pemón de la Gran Sabana, que colindan con Brasil, y que se afirma están a su vez en migración, también son muy poetas en su expresión. Largo sería aquí poner tantos ejemplos. Deseáramos por tanto, que los colegas antropólogos brasileños, que son tan sensibles y 
profesionales a la vez, estudiaran a los warao desde el punto de vista étnico, y a cada uno de estos pueblos ahora en migración, mientras estén allí, como lo que son, representantes originarios de un pasado remoto que tienen mucho que ofrecer al mundo de la ciencia por sus saberes tradicionales y por su resiliencia de vivir.

Los warao, en un ambiente de río, con más de tres mil caños que han logrado mantenerse como un pueblo de agua por lo menos 5.000 años o más y cuyos orígenes lingüísticos aún son desconocidos para la ciencia Antropolingüística actual y no deseáramos que sean simplemente vistos como unos migrantes más, con necesidades, pobreza y enfermedades, y algunos, con ciertos comportamientos inadecuados, copia de las culturas de la dominación que por fuerza de la moda, las escaseces, insuficiencias y en crisis, las han debido agudizar. Podríamos asegurar y quizá no equivocarnos- que los warao volverán a sus caños en el Delta del Gran Río Orinoco, a quien ellos reconocen con todo respeto, como su Río Padre, pero si deciden formar otro pueblo en los territorios brasileños, les deseamos de toda buena voluntad, los mejores deseos para este logro, y esperamos que los hermanos indígenas del Brasil, los acojan con las mejores intenciones, que no los vean como invasores, sino, como unos hermanos lejanos que quizás, hace más de 10.000 años también emigraron de esas regiones del Sur para ubicarse en el gran Delta del Río Orinoco, a quien consideran hoy, su Río Padre, pero que también, forma parte de la Gran Cuenca del Río Amazonas, como lo demuestra el mito genésico de Amalivacá, que aún sigue siendo relatando por los grandes narradores de los pueblos indígenas del Orinoco.

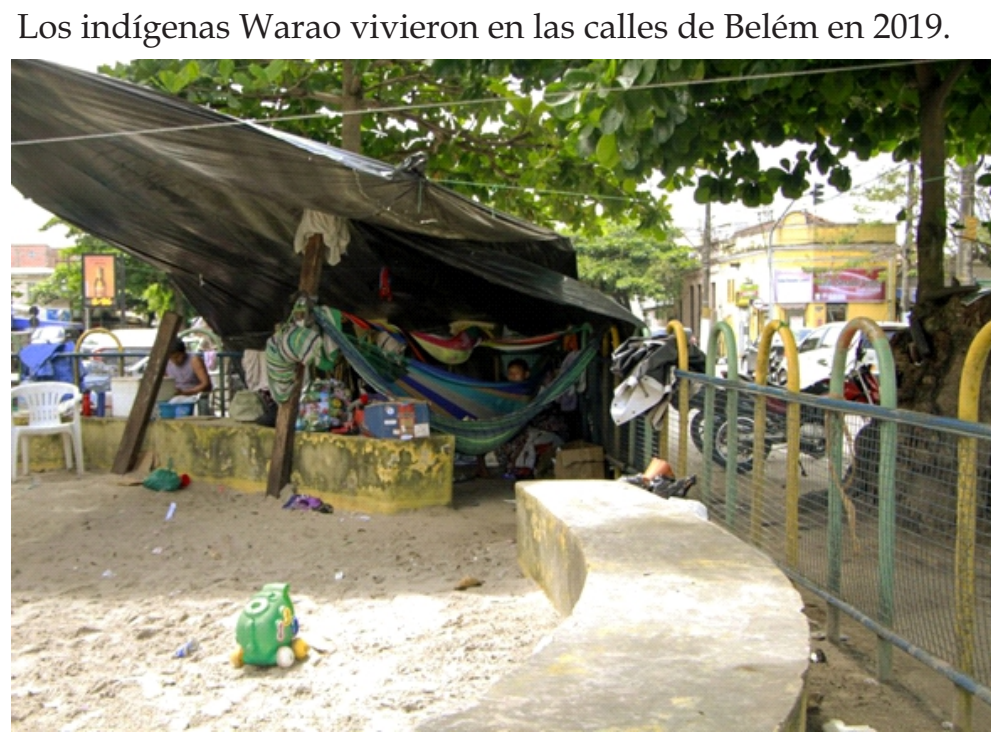

Foto: Roberta Brandão / Amazônia Real.

En el refugio indígena warao hacen artesanías en Boa Vista (RR)

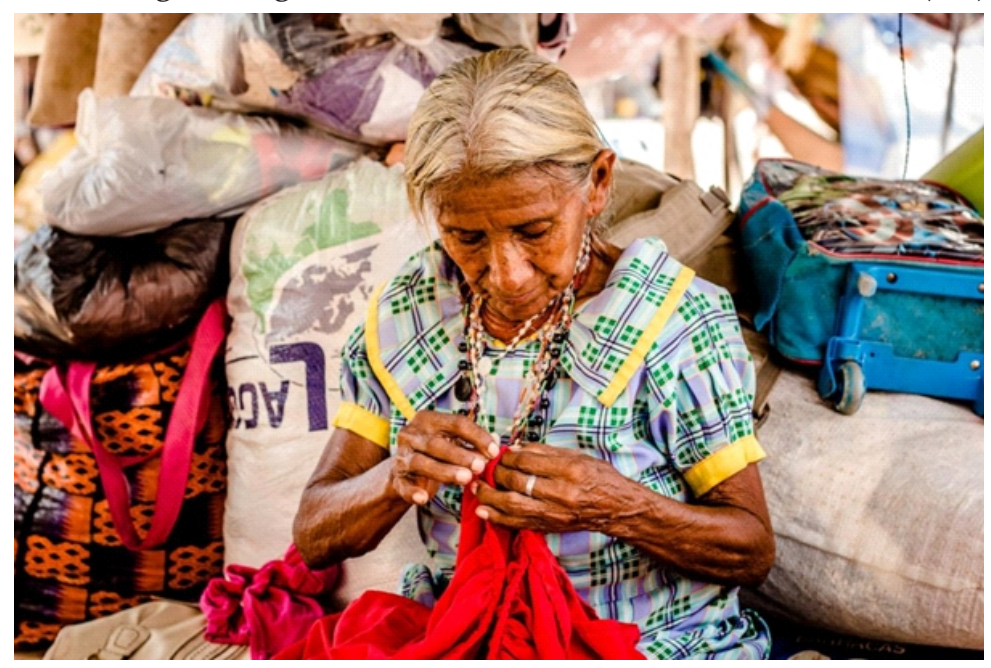

Foto: Yolanda Simone Mêne / Amazônia Real / 2016 


\section{Referencias bibliográficas}

ACNUR. Nota Informativa para municipios sobre la llegada espontánea de población venezolana incluyendo indígenas. 2019. Disponível em: <https://www.acnur.org/portugues/publicacoes/>. Acesso em: 12 de agosto de 2020.

ARMELLADA, Cesáreo de y BENTIVENGA DE NAPOLITANO, Carmela. Literaturas Indígenas Venezolanas. Monte Ávila Editores. Caracas. Venezuela, 1991.

BARRETO, Daysi y MOSONYI, Esteban E. Literatura Oral warao. Caracas: Coordinación de Literatura, Ediciones Consejo Nacional de la Cultura, 1980.

BARRAL, Basilio María de. Los indios Guaraúnos y su cancionero: historia, religión y alma lírica. Biblioteca "Missionalia Hispánica", Vol.15. Madrid: Consejo Superior de Investigaciones Científicas, Dep. De Misionología Española, 1964.

. Guarao A-Ribu. Universidad Católica Andrés Bello. Págs. 304. Venezuela, 1969.

. La Música Teúrgico-Mágica de los Indios Guaraos. Publicado en Revista Montalbán, Nº 10. 1980. Pp. 7 a 201.

BERMÚDEZ, Beatriz. Jojomare. Música y baile Warao. Fundación Cultural Chacao. Caracas. Venezuela, 1999.

CORA, María Manuela de. Kuai-Mare. Mitos Aborígenes de Venezuela. Monte Ávila Editores. Caracas. Venezuela, 1972.

ESCALANTE, Bernarda \& MORALEDA, Librado. Warao a rejetuma. Fundación La Salle. Caracas: Cultura e Historia, 1992.

GARCÍA, Argimiro. Cuentos y tradiciones de los indios Guaraúnos. Universidad Católica Andrés Bello. Caracas. Venezuela, 1971.

GARCÍA-CASTRO, Álvaro A. "De pescadores y agricultores a obreros: el impacto socioeconómico del cierre del caño Manamo entre los Warao del delta Occidental". L Convención anual. 50 años AsoVAC. 23 de noviembre. Auditorio de la Biblioteca. Universidad Simón Bolívar (USB). Caracas, 2000a.. (Publicado en: Monografías. com).

“Mendicidad Indígena: Los Warao urbanos". En: Boletín Antropológico. (Revista arbitrada del Centro de Investigaciones Etnológicas y el Museo Arqueológico de la Universidad de Los Andes (ULA). Mérida). Nro 48: Enero/abril, 2000b. (79-90).

."Mendicidad Warao en Caracas". En: Revista Bigott. N 56. Agosto-septiembre-octubre. Caracas: Fundación Bigott, 2001.

.y HEINEN, Dieter. “Planificando el Desastre Ecológico. El cierre del Caño Manamo en el Delta del Orinoco, Venezuela", en Antropológica. Caracas: Instituto Caribe de Antropología y Sociología (ICAS). Fundación La Salle. 91, (31-56), 1999.

GILIJ, Felipe Salvatore. Ensayo de Historia Americana. Tomo III. Volumen No, 73. Publicaciones Biblioteca de la Academia Nacional de la Historia. Fuentes para la Historia Colonial de Venezuela. Caracas, 1965. 
GUANIRE, Noreye; ARANGUREN, B. \& GONZÁLEZ ÑÁÑEZ, Omar. Etnobotánica Medicinal de los indígenas Warao de Tucupita y de la Isla De Araguabisi en el Estado Delta Amacuro, Venezuela, en Boletín Antropológico. Año 28, N 79, Mayo-Agosto, Universidad de Los Andes. pp. 139-1582010.

HEINEN Dieter. Aportes para una etnografía Warao. Caracas: ICAS. Instituto Caribe de Sociología y Antropología, 1980.

. "Estructura social y mecanismos de desintegración en la sociedad Warao." In: Acta Científica Venezolana 33(5):419-423, 1982.

. OkoWarao: Marschland People of the Orinoko Delta. Münster: Lit. Verlag, 1988a.

. “Los Warao." In: Walter Coppens (Ed. Gen.). Los Aborígenes de Venezuela, Vol. III. Etnología contemporánea. Fundación La Salle de Ciencias Naturales. Instituto Caribe de Antropología y Sociología. Monografía no. 35. Caracas: Monte Ávila Editores, 1988b.

."The early colonization of the Lower Orinoco ant its impact on present day indigenous peoples." In: Antropológica, 78: 51-86, 1992.

HUMBOLDT, Alexander Barón. Del Orinoco al Amazonas. Editora Labor, España, 1967.

KOCH GRÜMBERG, Theodor, Del Roraima al Orinoco.- Tomo II.- Ediciones del Banco Central de Venezuela. Caracas, 1981. Edición original en alemán, Stuttgart. 1924.

LAVANDERO PEREZ, Julio. Uaharaho. III.- Ethos Narrativo. Ediciones de los Hermanos Capuchinos.- Caracas, Venezuela, 1994.

MEDRANO Carmen y MORAL, Berenice del. Naba a Rohutuma. Voces musicales del agua. Ediciones Consejo Nacional de la Cultura. Colección Cada Día un Libro. Ministerio de la Cultura. Caracas, 2005.

MEGGERS, Betty. Amazonia. Hombre y Cultura en Un Paraíso Ilusorio. Siglo XXI, Editores. México, 1976.

MOSONYI, Esteban Emilio. El indígena venezolano en pos de su liberación definitiva. Editorial El perro y la rana. Venezuela, 2008.

MPF. Parecer Técnico Warao, 2017. Disponível em: <http://www.mpf.mp.br/am/sala-deimprensa/docs/parecer-tecnico-warao/view>. Acesso em: 12 de agosto de 2020.

PEREIRA, Gustavo. El legado indígena. Biblioteca Básica Temática. Consejo Nacional de la Cultura. Caracas, 2004.

ROSA, Marlise. La movilidad de los Warao y los desafíos para la gestión de una población en tránsito. Qualificação de tese de Doutorado em Antropologia Social. Rio de Janeiro: UFRJ, 2019.

. Los viajeros: notas sobre a mobilidade Warao no Brasil. In: 20 anos depois: a contemporaneidade do pensamento de Abdelmalek Sayad.São Paulo: Pontifícia Universidade Católica, 2018.

SUAREZ María Matilde. Los Warao. Editora Venegráfica. Caracas, 1968.

SANTOS, Izabel, e MATOS, Vivianny. Coronavírus: Amazonas e Pará registram quatro casos em indígenas venezuelanos. Um homem Warao morreu. Amazônia Real - Povo Indígenas,17 de abril de 2020. Disponível em: <https://amazoniareal.com.br/coronavirus-amazonas-e-pararegistram-quatro-casos-em-indigenas-venezuelanos-um-homem-warao-morreu/>. Acesso em: 12 de agosto de 2020.

EntreRios - Revista do PPGANT -UFPI -Teresina • Vol. 3, n. 2 (2020) 
VAQUERO ROJO, Antonio E. Tradición oral entre los Waraos. Universidad Católica Andrés Bello. Caracas, Venezuela, 2011.

VELÁSQUEZ, Ronny. Estética Aborigen. FUNDARTE y FINIDEF. Caracas, Venezuela, 2008. . Mitos de Creación de la Cuenca el Orinoco. Editorial El Perro y la Rana. Caracas, 2018.

VELÁSQUEZ, Ronny. Estudio Bibliográfico comentado e interpretado sobre las Literaturas Indígenas de Venezuela. UCV. Caracas, 2016.

WILBERT, Johannes. Textos folklóricos de los indios Warao. University of California. Los Ángeles, Estados Unidos, 1969.

$5(1):(129-150), 1979$.

"Geography and telluric lore of the Orinoco Delta". En: Journal of Latin American lore. $\mathrm{N}^{\circ}$

"Rasgos Culturales Circuncaribes entre los Warrau y sus Inferencias". En: Memoria. Caracas: Sociedad de Ciencias Naturales La Salle. Tomo XVI, N 45, (237-257) 1956a.

WILBERT, Werner. Fitoterapia Warao. Caracas: Instituto Caribe de Antropología y Sociología (ICAS). Fundación La Salle de Ciencias Naturales, 1995.

- y LAFÉE, Cecilia Ayala. La mujer warao de recolectora deltana a recolectora urbana, ICAS, Fundación La Salle de Ciencias Naturales, 2008.

. "Conceptos etnoecológicos Warao." En: HEINEN, H. Dieter, SAN JOSÉ, José J. y CABALLERO ARIAS, Hortensia. Scientia Guayanae. Instituto Venezolano de Investigaciones Científicas (IVIC) Caracas: (335-370), 1995. 